\title{
The European Union and the Principle of Self-determination of peoples: Territories with Special Status in the European Union and Pending Cases of Decolonization
}

\author{
José Manuel SOBRINO HEREDIA*
}

\begin{abstract}
The European Union gives special status to a number of countries and territories that maintain particular political and administrative ties with several of its Member States. Despite the diversity of these entities, it is possible to identify two main trends in them. On the one hand, the ones that want to pursuit political and administrative assimilation with their metropolises, and, on the other hand, the others that would like a greater autonomy or even independence from the states on which they depend. The present paper will examine these trends and processes. The First Part will focus on the current legal basis for outermost regions and overseas countries and territories in the EU law and in the Member States' domestic law. The Second Part will examine how the special situations of these entities have led, in some cases, to their assimilation with the state on which they depend, in others, to a greater autonomy, and, in still others, to independence.
\end{abstract}

Keywords: European Union - Self-Determination of Peoples - Territories with Special Status - Decolonization - Referendum.

\section{INTRODUCTION}

Since it was founded, the European Union has given special treatment to a number of countries and territories that, as a result of historical, political or geographic circumstances, maintained and, in some cases, continue to maintain particular political and administrative ties with several of its Member States. In the intervening years, the number of such territories has varied considerably, largely due to the process of decolonization that allowed many of them to achieve independence and change their relationships with the EU. ${ }^{r}$ Nevertheless, there remains a diverse group of territories scattered around the world with a special status within the Union. Some are part of it; others are not. Consequently, the European legal system applies to them to varying degrees.

Professor of Public International Law, Universidade da Coruña.

I As these overseas countries and territories achieved independence, they concluded or acceded to partnership and development cooperation agreements with the EU, which, since the first Yaoundé Convention, signed in 1963, up to the current Cotonou Partnership Agreement, signed in 2000, have afforded them special treatment. 
Each of these territories, which give the EU its planetary dimension, has its own special features. They differ in terms of their economic situation, populations and politicaladministrative organization. Many share a remoteness from the European continent, insularity, small size, the consequences of climate change, demographic growth or emigration. ${ }^{2}$ Their political-administrative statuses are diverse, and they are subject to different jurisdictions, which vary depending on their links to the states on which they depend. They are also given different names: territorial collectivities, autonomous communities, departments, countries, autonomous regions, territories, etc. Moreover, many of them are home to autonomist or separatist movements that advocate for greater autonomy or, directly, independence based on the principle of self-determination of peoples.

Despite the diversity of these territories, and the unique histories and geographies that have given rise to their specific characteristics and socio-economic and political evolution, it is possible to identify two main trends in them. On the one hand, the ones that want to pursuit political and administrative assimilation with their metropolises, and, on the other hand, the others that would like a greater autonomy or even independence from the states on which they depend. This dichotomy has been visible in the various plebiscites and referenda held in many of these territories to date, and its consequences have been felt not only in the affected Member States themselves, but also within the EU as a whole.

No provision of the Treaties related to these categories of territories makes any reference to the principle of self-determination of peoples, but rather to the commitment to promote their economic and social advancement, along the lines of Article 73 of the UN Charter. For the EU, the statuses of these territories are an internal matter for the Member States. In accordance with Article 4.2 TEU, it has thus respected, without interfering in, the ways in which these Member States, in keeping with their political and constitutional structures, have organized their relations with their overseas territories. Where applicable, it has also facilitated these processes to grant greater autonomy or independence in accordance with international law. In other words, the EU has only intervened to regulate the legal, political and economic consequences of these processes for the European legal system. ${ }^{3}$ Hence, the granting by the Union to these territories of a special or differentiated status is in no case, from the perspective of EU law, the prior step to their separation from the states on which they depend. Rather, it is the recognition of their special political-administrative status within those states and, therefore, their unique inclusion within the territorial scope of application of that law.

2 Most have a GDP 30 to $50 \%$ lower than that of their European metropolises, although they are relatively prosperous islands compared to their closest neighbours.

3 J. Martín y Pérez de Nanclares: "Reflexiones jurídicas a propósito de una eventual declaración unilateral de independencia de Cataluña: un escenario político jurídicamente inviable", Real Instituto Elcano, 24 September 2015 , at 22-23. 
At present, territories with special status in the EU can basically be grouped into two categories: Outermost Regions (ORs) and Overseas Countries and Territories (OCTs). The former, with a few exceptions, are subject to European law (Articles 349 and 355 TFEU). In contrast, the latter are subject not to EU law, but to a particular association regime (Articles 198 to 204 TFEU). In the former, a trend can be found towards assimilation with the Member State on which they depend, whilst the latter are home to movements of varying degrees of intensity in favour of greater autonomy or, even, independence. Notwithstanding these differences, supporters of both integration and rupture with the metropolis can be found in both groups.

The present paper will examine these trends and processes affecting the territories with special status in the EU. The first part will explore the current legal basis for ORs and OCTs in EU law and in the Member States' domestic law (A). The second part will look at how this situation has led, in some case, to the assimilation of these territories with the state on which they depend, in others, to greater autonomy, and, in still others, to independence (B).

\section{(A) THE LEGAL BASIS FOR TERRITORIES WITH SPECIAL STATUS IN EU LAW AND MEMBER STATES' DOMESTIC LAW}

\section{(I) Territories with Special Status in EU Law}

Regardless of what the overseas territories are called in the Member States' domestic law, EU law, as noted, distinguishes between outermost regions (ORs) and overseas countries and territories (OCTs). Additionally, several Member States include entities with particular or special legal statuses, which, in turn, has consequences for the EU. This situation is complicated by the fact that, over the course of their history, the legal status of these territories can change, shifting from one category to another.

\section{(a) Outermost Regions}

The EU has nine ORs. They consist of islands, archipelagos, and a continental territory and are located in the Caribbean basin, the West Atlantic and the Indian Ocean or in territory close to the Amazon rainforest. They have a population of around 5 million people and account for a large part of the EU's maritime territory (some 25 million $\mathrm{km}^{2}$ ). They differ from each other, and each has its own specific needs. They are mentioned in Article 349 TFEU and include territorial collectivities, departments, regions and autonomous communities, namely: Guadeloupe and Réunion (2 French regions); Mayotte and Saint Martin (2 French overseas departments); French Guiana and Martinique (2 French territorial collectivities); Madeira and the Azores (2 Portuguese autonomous regions); and the Canary Islands (I Spanish autonomous community). 
These regions, despite being separated by thousands of kilometres from the European continent, are an integral part of the Union. They are subject to EU law and to all the rights and duties associated with EU membership, except where otherwise provided by specific derogations or measures. ${ }^{4}$ The ORs' special status has been recognized in the EU's treaties since 1999. Since 2009, it has been recognized in the aforementioned Article 349 TFEU, which warns that these regions have special characteristics that differ from the rest of the EU and constrain their economic and social development, placing special emphasis on factors such as their remoteness, insularity, small size, difficulty topography and climate, and economic dependence on a few products. This enables the adoption, within the European legal framework, of specific measures adapted to these special characteristics. ${ }^{6}$ This provision applies in combination with Article 355.I TFEU. In addition to referencing the specific nature of the measures to be applied to these regions, it helps define the territorial scope of EU law. As Ziller has noted, the EU legal regime applicable to the ORs is that of integration-adaptation, meaning that EU law is normally applicable to these territories, unless otherwise expressly provided.7

Another provision referring to the special status of the ORs is Article 107.3 (a) TFEU, which assimilates it to that of areas with an abnormally low standard of living or serious underemployment and, thus, considers aid to promote their economic development compatible with the internal market. Meanwhile, the EU must consider the ORs' interests in matters falling within its sphere of competence, such as trade, fisheries, agriculture, etc., that are particularly sensitive sectors for them.

These regions are home to processes of assimilation, autonomy and independence with regard to the states on which they depend. In the European archipelagos in the Western Atlantic (the Canary Islands, the Azores and Madeira), there is predominantly a movement

4 The applicability to the ORs of specific and/or derogating legislative and non-legislative measures with regard to a variety of European policies, considering their specific economic and social situations, determines the components of their special status within the EU. Communication from the Commission to the European Parliament, the Council, the European Economic and Social Committee, the Committee of the Regions and the European Investment Bank. "A stronger and renewed strategic partnership with the EU's outermost regions", COM (2017) 623 Final, 25 October 2017.

5 On the legal and political framework of the ORs in the EU, see, amongst others: P. Guillaumin, "La dimension ultrapériphérique de l'Union européenne”, in J.-D. Hache (ed.), Quel statut pour les îles d'Europe? (L’Harmattan, Paris, 2000) 103-127; I. Omarjee, "Les régions ultrapériphériques", in Répertoire de droit communautaire Vol. IV (Dalloz, 2005 edition) I-I6; J.M. Sobrino Heredia and M. Sobrido Prieto, "Las regiones ultraperiféricas", 5 Revista Hacienda Canaria (Consejería de Economía y Hacienda, Gobierno de Canarias, October 2003) 5-36.

6 The judgment of the Court of Justice of the EU of 15 December 20I4, Ci32/I4, in European Parliament and European Commission v Council of the European Union, clarified the scope of Article 349 TFEU.

7 J. Ziller, "Les États européens et les territoires ultra-marins placés sous leur souveraineté", 35 Nouveaux Cabiers $d u$ Conseil constitutionnel (April 20I2) at I. 
towards assimilation. In contrast, all three trends co-exist in the French regions, with the predominance of any one depending on the internal situation of the region in question.

\section{(b) Overseas Countries and Territories}

The EU also maintains special relations with other territories that, although scattered across the world, are linked to four of its Member States by special ties. ${ }^{8}$ We are referring to the overseas countries and territories (OCTs) to which the Union grants the status of associated territories, as provided for in Part IV TFEU (Articles 198-204). They are not independent states, because they still have special relations with Denmark, France, the Netherlands or the United Kingdom (Article 198 TFEU). Neither are they part of the EU or the single market, nor does EU law automatically apply to them. Nevertheless, the Union seeks to promote their economic and social development and to establish close economic relations with them. Whilst EU law does not apply to the OCTs, the principles relating to individuals (in particular, EU citizenship and human rights) do, albeit only if these individuals have the full nationality of an EU country, 9 in particular, the right to participate in the elections to the European Parliament. ${ }^{\mathrm{IO}}$ Additionally, they receive resources from the $\mathrm{II}^{\mathrm{th}}$ European Development Fund (EDF) for 2014-2020 and benefit from the aid of the European Investment Bank (EIB). The TFEU and its secondary law do not automatically apply to the OCTs, except for some provisions that explicitly state otherwise. Additionally, the degree of self-government and individual powers of the various OCTs depends on their special relationship with the Member State to which they are linked.

Annex II TFEU lists the 2I OCTs to which the provisions of Part IV TFEU apply. They are as follows: Greenland; New Caledonia and Dependencies; French Polynesia; French Southern and Antarctic Territories; Wallis and Fortuna Islands; Saint Pierre and Miquelon; Saint Barthélemy; Aruba; West Indies (Bonaire, Curaçao, Saba, Sint Eustatius, Sint Maarten); Anguilla; Cayman Islands; Falkland Islands; South Georgia and the South Sandwich Islands;

8 European Commission, "Green paper - Future relations between the EU and the overseas countries and territories", COM (2008) 383 final, Brussels, 23 May 2008.

9 Under Article I7 of the Treaty establishing the European Community, every person holding the nationality of a Member State shall be a citizen of the Union. In fact, all nationals of Greenland and of the French and Dutch overseas countries and territories (OCTs) also automatically hold the nationality of the corresponding Member State, making them EU citizens. Since 2I May 2002, the citizens of all British OCTs are also British citizens, but they may renounce that citizenship and be only British Overseas Territories citizens.

ro The CJEU ruled against the Netherlands for not granting the inhabitants of Aruba the right to vote in European elections. Judgment of I2 September 2016, C-300/04, M. G. Eman and O.B. Sevinger v College van burgemeester en wethouders van Den Haag. 
Montserrat; Pitcairn; Saint Helena and Dependencies; British Antarctic Territory; British Indian Ocean Territory; Turks and Caicos Islands; British Virgin Islands; and Bermuda. ${ }^{\text {II }}$

The OCTs have a total population of just over one million people. The most populous countries and territories are New Caledonia and French Polynesia, each of which has a population of around 270,000 people. At the other extreme, some OCTs are barely inhabited at all, or only inhabited by scientists and military personnel. That is the case of the French and British Antarctic Territories, the Pitcairn Islands and the Sandwich Islands. This large demographic disparity is further compounded by a large geographic disparity. Greenland, for instance, is a sprawling territory, spanning more than 2 million $\mathrm{km}^{2}$. In contrast, other islands are very small, such as the Pitcairn Islands in the Pacific, which have a total area of only $47 \mathrm{~km}^{2}$.

Article 199 TFEU lays out the objectives of the association with the OCTs, related to trade, investments and the right of establishment of nationals and companies. Additionally, since I January 2014, these relations have been governed by the Overseas Association Decision [Council Decision 2013/755/EU, of 25 November 2013, on the association of the overseas countries and territories with the European Union], ${ }_{\text {,2 }}^{\mathrm{r}}$ wich emphasizes that "the solidarity between the Union and the OCTs should be based on their unique relationship and their belonging to the same "European family". In short, it is an association conceived of as a framework for policy dialogue and cooperation on issues of mutual interest (Article 5.I of the Decision). Furthermore, "[i]n pursuing these objectives, the association shall respect the fundamental principles of liberty, democracy, human rights and fundamental freedoms, the rule of law, good governance and sustainable development, all of which are common to the OCTs and the Member States to which they are linked" (Article 3.3 of the Decision). From an institutional perspective, the dialogue between the EU and the OCTs is channelled through an annual forum and regular trilateral meetings between the Commission, all the OCTs, and the Member States to which they are linked, and meetings of associates (the Commission, individual OCTs, and the corresponding Member States).

In short, as non-European territories that have special relations with a Member State, the OCTs are excluded from the territorial scope of EU law. However, they are included within the personal scope of EU law, as their nationals, with a few exceptions, have EU citizenship. Therefore, they have inherited an ambivalent situation, marked by a differentiated and specific integration, but also by de facto and, at times, de jure assimilation to third countries. ${ }^{13}$ Moreover, as will be seen below, all have witnessed the emergence of movements seeking to strengthen

II Although Bermuda has the status of a British overseas territory, it chose not to apply to the EU for that same status. Consequently, the association regime was not applicable in that territory. Under the TFEU, Bermuda could apply to be recognized by the EU with the status of OCT, which occurred in 2014 .

I2 OJ L344, I9 December 2013, at I.

I3 T. M'Saïdié, Les pays et territoires d'outre-mer dans l'Union Européenne (E. Bruylant, Brussels, 20I3). 
their integration with the metropolis, attain a higher level of autonomy, or even achieve independence.

\section{(c) Other Territories with a Differentiated Status}

Finally, there is a group of territories that, although they do not fall within the categories of ORs or OCTs, has a differentiated status in the EU due to their special constitutional links with various Member States. These are very diverse territorial entities, mostly of them are located on the European continent with very different degrees of autonomy with regard to the Member States on which they depend. These territories include: the Alland Islands; two German localities (Büsingen am Hochrhein and Heligoland); two Italian localities (Campione d'Italia and Livigno); two Spanish autonomous cities (Ceuta and Melilla ${ }^{\mathrm{I}}$ ); one British overseas territory (Gibraltar ${ }^{15}$ ); one Greek autonomous territory (Mount Athos); and the British Sovereign Base Areas of Akrotiri and Dhekelia in Cyprus. ${ }^{16}$

\section{(d) Changes in the Special Status}

EU law includes rules that allow changes in the special status that the Union grants to these territories in the event of political-administrative changes in their relations with the states on which the depend. These rules are intended either to facilitate the transformation of ORs into OCTs or vice versa or to provide for a possible independence. However, the changes themselves are the sole responsibility of the Member States; the Union simply facilitates the processes, without interfering in them.

Thus, Article 355.6 TFEU, the so-called "passerelle clause", makes it possible to change the status of these territories without amending the Treaties. It does so by enabling the European Council, on the initiative of the Member State concerned, to adopt a decision amending the

${ }^{14}$ The autonomous cities of Ceuta and Melilla each have their own Statute of Autonomy, passed, respectively, by Organic Laws I/1995 and 2/1995, I3 March 1995, as provided under Art. I44.b of the Spanish Constitution. They are part of the European Union with certain mainly customs- and tax-related exceptions. This specific treatment was expressly provided for in the Act of Accession of Spain and Portugal to the European Communities (Arts. 25 and 155 of the Act of Accession and Protocol 2).

is Gibraltar is a European territory whose foreign relations are assumed by a Member State. The 1972 Treaty of Accession of the United Kingdom establishes a special status for Gibraltar. Gibraltar is not an integral part of the United Kingdom, but rather a territory under British sovereignty, for whose external relations the United Kingdom is responsible. Therefore, in accordance with Art. 355.3 TFEU, EU law is applicable to it, with some exceptions, including those provided for in the Act of Accession of the United Kingdom, which excludes Gibraltar from the common customs territory and the Common Commercial Policy, the Common Agricultural Policy, the Common Fisheries Policy, and the obligation to collect value-added tax (VAT). Gibraltar is not part of the Schengen Area.

${ }^{16}$ There are also some territories that, although they maintain constitutional ties with Member States, do not have them with the EU, but rather remain legally unrelated to it. They are the Faroe Islands (Denmark) and the so-called British crown dependencies (Isles of Man, Guernsey and Jersey). 
status with regard to the EU of a Danish, French or Dutch OCT. Additionally, Article 97 of the Overseas Association Decision provides for the possibility and consequences that an OCT might become independent, leave the association or become an OR.

It was through the aforementioned "passerelle clause" that Mayotte — which became a French department in March 20I- came to have the status of an OR. Under that article, France submitted a request to change the status to the European Council, which unanimously decided to accept Mayotte's transformation into an OR as of I January 20Ir. This could also happen in the Netherlands Antilles, whose political-administrative status was changed in the 2010 constitutional reform. Some of the territories became Dutch municipalities, whilst others became independent countries within the Kingdom of Holland, opening up the possibility that their current status of OCTs could be transformed into ORs.

The opposite occurred with regard to the French overseas collectivity of Saint Barthélemy, which, until 20II, was an OR. However, given its remoteness from the metropolitan territory, its specific legal status, its close economic relations with partners in the Americas, and the emphasis it places on tourism, France requested a change in its status, turning Saint Barthélemy into one of the Union's OCTs.

It is also worth recalling that, following the results of the 1982 referendum in favour of Greenland's withdrawal from the EEC, the Danish government - as the party responsible for doing so - submitted a memorandum to the EC Council of Ministers. Denmark proposed a series of amendments to the Treaties in order to add Greenland to the list of OCTs listed at the time in Annex IV of the EEC Treaty. The 1984 treaty enabled this transformation. EU law ceased to be applied in Greenlandic territory, and relations with Greenland instead came to be governed by the association regime. As is well known, this transformation was not accompanied by Greenland's secession from the Kingdom of Denmark, of which it continues to be a part. However, it did result in a reduction of the territorial scope of EU law. In contrast, if the process had entailed Greenland's separation from Denmark, based on existing practice with regard to OCTs that have become independent, or on the very specific precedent of Algeria, ${ }^{17}$ it would have signified its transformation into a third country with regard to the Union and the termination of the association regime.

${ }^{17}$ Algeria was specifically mentioned, as a French department (part of the French Republic), in the Treaty of Rome (1957). It fell under the territorial scope of the TEEC, with the "modulations" provided for in Art. 227, a case of "partial application" of the treaties. Algeria's independence in 1962 meant its exit from the EEC, although this outcome had not been provided for in EEC Treaty. The withdrawal was never formalized in any treaty. Indeed, for years, Algeria continued to be mentioned within the territorial scope of European law, until the reference was eliminated from the text in the Treaty of Maastricht in 1992, when France modified the scope of its territory with the tacit consent of the other Member States. 
With regard to these cases and how they might apply to new similar situations, as practice has shown, the initiative corresponds to the Member State concerned, and the execution of the process falls within the scope of its sovereignty. Therefore, in the author's view, neither the Commission nor the Council should assess the advisability of such requests for changes in the status of such regions and territories, or of their potential independence. Rather, the European institutions' actions should be limited to making the necessary amendments to EU law to accommodate such political-administrative changes.

(2) Territories with Special Status in Member States' Domestic Law

\section{(a) French Overseas Territories}

Several territorial collectivities, the legacy of France's colonial past, still maintain different political-administrative ties with the French Republic. These "poussières impériales" have different degrees of autonomy with regard to continental France and maintain their special local features. In all, overseas France comprises twelve such territories: Saint Martin, Saint Barthélemy, Guadeloupe and Martinique, in the Caribbean and West Indies; French Guiana in South America; Saint Pierre and Miquelon, in North America; French Polynesia and the islands of Wallis and Futuna, New Caledonia and Clipperton in the Pacific Ocean; Mayotte and Réunion in the Indian Ocean; and, finally, the French Southern and Antarctic Territories. ${ }^{18}$

They are classified according to three political statuses: overseas departments (départements d'outre-mer or DOMs), overseas territories (territoires d'outre-mer or TOMs), and territorial collectivities (collectivités territoriales or CTs). The DOMs have been considered French departments since 1946. Law 821171, 31 December 1982, granted them the status of monodepartmental regions, turning them into overseas regions (ORs) and, thus, the overseas departments and regions (départements et régions d'outre-mer or DROMs) that are part of the EU. These regions are subject to French law, the inhabitants are entitled to vote, the currency is the euro and the education system is the same as in metropolitan France. They also have the same powers as the metropolitan regions. ${ }^{19}$ Under Article 73 of the French Constitution, the DROMs are subject to the system of legislative assimilation. They exercise the legal powers common to the departments and regions, but also participate in international negotiations and have greater right of initiative. The DROMs include, amongst others, France's oldest colonies:

I8 Some 2.6 million people live in the overseas departments and territories, I.2 million of whom are minors. This overseas portion of France makes it the country with the largest extension of jurisdictional waters, after the United Sates and ahead of Australia. The French EEZs span a total of in million $\mathrm{km}^{2}$. Some $97 \%$ of this surface is overseas.

I9 A. Roux, "L'évolution constitutionnelle du statut des départements d'outre-mer", (30 January 2017). See also: L. Bleriot, "Les départements et régions d'outre-mer: un statut á la carte", II3 Pouvoirs (2005). F. Lucharie, Le statut constitutionnel de la France d'outre-mer (Ed. Economica, Paris, 1992). 
Guadeloupe, Martinique, French Guiana, Réunion and Mayotte. As noted above, the latter acquired the status of DROM in 20II, making it the IOI $^{\text {st }}$ French department. In 2016, Martinique and Guiana also became single collectivities.

As for the TOMs, following the 2003 reform of the French Constitution, they became overseas collectivities (collectivités d'outre-mer or COMs), which gave them greater autonomy. A COM is a French administrative division that includes the territories governed by Article 74 of the French Constitution, corresponding to the former overseas territories and other collectivities with special statuses. There are five COMs. On 27 February 2004, French Polynesia negotiated a special status by the name of "overseas country" (pays d'outre-mer), granting it a certain level of self-government, with a president and diplomatic representation in the Pacific area. Saint Barthélemy and Saint Martin, formerly part of the DOM of Guadeloupe, became autonomous collectivities on 22 February 2007. Saint Pierre and Miquelon, formerly a DOM, became a territorial collectivity in 1985 ; they have a status similar to that of the departments, with a general council. Finally, Wallis and Futuna, in the Pacific Ocean, also has a specific status. A former TOM, it became a COM following the 196I reform of the Constitution. It is the only inhabited French territory that is not subdivided into communes or municipalities. Furthermore, it is made up of three traditional monarchies. The COMs and the French Southern and Antarctic Territories ${ }^{20}$ have a special status with regard to the EU. They have autonomy in customs and tax matters and their own social welfare systems. France provides their security.

New Caledonia, which is governed by Title XIII of the French Constitution, is a sui generis collectivity with a status falling somewhere between that of an independent country and an overseas community. It has a territorial congress and a territorial government, which is responsible for matters such as health, taxes, customs, education, etc. It holds local elections and has speaking and voting rights in the French national assembly. As in French Polynesia, the currency is the Pacific franc. Articles 76 and 77 of Title XIII introduce the 1998 Nouméa Accord, which defines the state powers transferred to the institutions of New Caledonia, the rules of procedure of those institutions, the rules concerning citizenship, the electoral regime,

${ }_{20}$ The French Southern and Antarctic Territories (Terres australes et antarctiques françaises or TAAF) comprise the Crozet and Kerguelen archipelagos, the islands of Saint Paul and Amsterdam (in the sub-Antarctic zone), the Adélie Land (Antarctica), and the Scattered Islands (Europa, Glorioso Islands, Juan de Nova, Bassas da India and Tromelin) in the Indian Ocean. They have no permanent population, but rather bases that are home to 4 to roo people (scientists, technical and military personnel, and meteorologists). The military personnel and meteorologists stationed in the Scattered Islands are rotated every 30 to 45 days. The islands also host scientists. The bases in the three sub-Antarctic districts and Adélie Land host between 20 and roo people (scientists and technical staff) for periods ranging from six months to a year. The TAAF are French overseas collectivities with administrative and financial autonomy. They are under the authority of a Prefect, who also represents the French government and is in charge of the collectivity. 
employment and personal status, as well as the conditions and time limits for the people concerned in New Caledonia to vote on the attainment of full sovereignty.

Unlike the DROMs, the COMs and New Caledonia are subject to the principle of legislative speciality, governed, respectively, by Articles 74 and 77 of the Constitution: an organic law determines the status of each community and lists the laws that apply to it. The local assemblies may draft regulations within the scope of the law, excluding sovereign affairs.

Clipperton Island, off the Pacific coast of Mexico, is uninhabited and is directly administered by the French government in Paris. ${ }^{2 t}$

Little by little, institutional diversity is becoming the norm in the French overseas territories. Each territory benefits from the political system best aligned with its own reality, seeking greater autonomy, without necessarily implying its complete detachment from France, supported by its relations with the metropolis on the basis of a multifunctional democracy. Otherwise, the French Constitution, insofar as it applies to the matter at hand, provides for the possibility of the independence of these territories, based on the right to self-determination (Article 5.3 of the 1958 Constitution, supplemented by paragraph 2 of the Preamble of that Constitution). Thus, a possible future secession of New Caledonia or French Polynesia would not encounter constitutional barriers; rather, they are French territories that, due to their specific characteristics, could become sovereign states. ${ }^{22}$ However, this would be achieved via processes agreed upon with the competent authorities of the Republic and would in no case be unilateral processes of independence.

\section{(b) Dutch Overseas Territories}

The Kingdom of the Netherlands consists of four "independent countries": the Netherlands, Aruba, Curaçao and Sint Maarten. The latter three territories are in the Caribbean and, together with the islands of Saba, Bonaire and Sint Eustatius, are the last territories in America linked to this European country. This group of islands was formerly known as the Netherlands Antilles.

In 1986, Aruba, which has a population of just over 100,000 inhabitants, became an independent country within the Kingdom. In 2010, Curaçao, with a population of 145,000 , and Sint Maarten, with a population of 37,000 , followed in its footsteps. However, despite their status as "independent countries", these territories are not fully independent. The king of The Netherlands is the head of state and, although they have autonomy in internal affairs, the

${ }_{21}$ French sovereignty over the island was recognized in an arbitral award rendered by the King of Italy in 1931. However, this sovereignty has not been enshrined in the French constitution or by any legislative act of the country.

${ }^{22}$ In the past, this enabled the independence, following local referenda, of Comoros (1974) and Djibouti (1997). F. Luchaire, "La France d'outre-mer et la République", 3 Revue Française d'Administration Publique (2007), at 6. 
foreign policy and defence of Aruba, Sint Maarten and Curaçao continue to depend on this European country. All the inhabitants of the Dutch territories, regardless of whether they were born in Europe or the Caribbean, have the same type of Dutch passport.

The other Dutch islands in the Caribbean (Bonaire, Saba and Sint Eustatius) adopted, also in 2010, the status of "special municipalities" within the Netherlands, making them an integral part of the country with the same status as a European territory. At present, things have reached a certain impasse. The Federation of the Netherlands Antilles should have been dissolved by I July 2007, but the reform has been indefinitely postponed. The island territories of Bonaire, Saba and Sint Eustatius should have become Dutch municipalities with a special status, but their situation is not yet clearly defined. The Dutch constitutional framework would allow the independence of these territories. However, faced with that possibility, the various territories concerned have preferred either reinforced autonomy or assimilation with the metropolis, ${ }^{23}$ perhaps due to the challenges faced by other territories in the region that chose independence from the Netherlands in the past.

\section{(c) British Overseas Territories}

These are the remains of what was once the British Empire. Although they can be found in almost every corner of the world, the majority are in the Americas: Anguilla, Bermuda, the British Virgin Islands, Montserrat, the Cayman Islands, the Turks and Caicos Islands, the Falkland Islands, and South Georgia and the South Sandwich Islands. The UN Special Committee on Decolonization considers colonies all of these territories, except South Georgia and South Sandwich Islands, which do not have a stable population. The Falkland Islands and South Georgia and the South Sandwich Islands are moreover the subject of a long-standing dispute between the UK and Argentina, which claims sovereignty over them. This is also obviously the case with Gibraltar, which, since the Treaty of Utrecht of 1713 and its transformation, first, into a British colony in 1830 and, then, into an overseas territory in 1969 , has led to fraught relations between the UK and Spain.

From a political viewpoint, these enclaves are British territories, whose status derives from the British Overseas Territories Act of 2002. ${ }^{24}$ However, they are not part of the United Kingdom, which, strictly speaking, refers to Great Britain and Northern Ireland. They are

\footnotetext{
23 D. Kochenov, "Le Droit européen et le (con) fédéralisme néerlandais: une dynamique en évolution progressive”, in J-Y. Faberon et al. (eds.): Destin des collectivités politiques d'Océanie (PUAM, Aix-en-Provence, 20II).

24 Under the 2002 Act, with certain exceptions, any person who was a British Overseas Territories citizen when the law came into force on 2I May 2002 would automatically become a British citizen, with the right to establish him or herself in the United Kingdom (which would grant that person European citizenship). Any person who subsequently acquires British Overseas Territory citizenship may apply for British nationality, which the Secretary of State may grant as he or she sees fit.
} 
semi-autonomous territories that are difficult to classify. The UK oversees foreign policy, domestic police and security, some financial aspects, the public service and, more generally, "good governance". The territories are responsible for everything else: economic policy, immigration, healthcare, education, etc. Despite this autonomy, Queen Elizabeth II is the head of state and London sets the sovereign policy. These territories issue their own passports, and their inhabitants are British Overseas Territories citizens. However, since 2002, they have had the right to acquire British citizenship.

It should be noted that the British Overseas Territories are not the same as the Commonwealth, nor are they crown dependencies, such as the Channel Islands (Jersey and Guernsey) or the Isle of Man. A British crown dependency is under the sovereignty of the monarch of the United Kingdom but is not part of it and does not belong to the European Union. The Commonwealth of Nations is made up of 53 independent countries. Since 1950, it has not entailed any submission to the British crown. As noted, the British Overseas Territories are under British sovereignty, but are not part of the United Kingdom. They are not directly administered by the British government, but rather have their own. The UK is responsible for aspects related to sovereignty. These territories are not represented in the British Parliament. Each one has a governor appointed by the British monarch, who acts as the representative of "Her Majesty's Government". The governors have powers with regard to security in the territory and representation between the territory and the British government. They are generally from the UK, although some are naturals of the territory they govern.

Movements for self-determination are a minority in these places, as seen in the various plebiscites held in them on the matter: in Bermuda, Anguilla, the Turks and Caicos Islands, etc. Additionally, some of these enclaves are territories whose population has been expelled or displaced, as occurred on Diego Garcia Island25, or with populations has been implanted by the United Kingdom (e.g. in Gibraltar the "Llanitos", and in the Malvinas/Falkland Islands the "Kelpers"). They thus obviously support a policy of assimilation with the metropolis and, therefore, are unlikely to give rise to pro-independence movements.

The British "constitutional" framework allows for the independence of these territories. The UK government considers that, when appropriate, it will help each territory achieve independence, provided that the population has expressed its will to do so clearly and constitutionally. In fact, in one case (Turks and Caicos Islands), this has already occurred. However, the country concerned ultimately reversed course, preferring a status of home rule, without cutting relations with the metropolis.

25 A. Pigrau Solé, "El caso de la isla de Diego García: Territorios sin Derecho internacional, personas sin derecho" 3I Revista Electrónica de Estudios Internacionales (2016) I-36 [DOI: I0.17103/reei.31.0I] 


\section{(d) Territories Dependent on Denmark}

In the Danish case, there are two territories with special statuses. The first is the Faroe Islands, which maintain constitutional links with the Kingdom of Denmark, but not with the EU, which, de jure, is unrelated to them. The other is Greenland, which has the special status of an OCT.

In the case of the Faroe Islands, its citizens have voted on separation multiple times and, after 70 years, remain divided on the issue. In 1946, the region voted on independence. The "Yes" vote narrowly won, receiving $50.73 \%$ of the total $\mathrm{II}, 640$ votes cast, which represented a turnout of $67.5 \%$ at the time. Copenhagen rejected the separation outright, arguing that the margin was too slim. Nor were the Faroese separatists able to agree on how to implement it. This was for one main reason: two of the three most populous islands had voted for continued union with Denmark. The crown dissolved the island assembly and called new elections. The unionists increased their ranks and won. The independence movement ended up settling, two years later, for a home-rule agreement that granted the islands absolute power in all matters except defence, foreign affairs, the judiciary, and exchange policy. Seventy years on, the strength of the Faroese independence movement remains unchanged. In the most recent elections, held in 2015, the total share of the vote going to separatist parties was exactly the same as the "Yes" vote in the 1946 referendum: 50.7\%. Pro-independence parties won 17 of the 33 seats in a recordsetting election, with a turnout of $88.8 \%$. However, the most voted party was unionist: the social democratic SDP. The result was a coalition government of separatist and unionist parties that shared a common goal: to draft a new Constitution, including the right to selfdetermination of the Faroe Islands, on which the people of the islands would vote on 25 April 2018. However, the plan was ultimately postponed indefinitely, due to a lack of agreement between the Islands' parties on the content of the future constitution.

With regard to Greenland, it is the largest island in the world and the largest territory in the Americas under the sovereignty of a European state. Greenland, which is home to around 60,000 people, is an autonomous country within the Kingdom of Denmark. In I8I4, it became a Danish colony, but that status has undergone changes. In 1953, it became a Danish overseas territory, and in 1979, it obtained its own parliament and limited self-government. When Denmark was negotiating its accession to the European Communities, this territory did not have a statute of autonomy. However, disregarding Greenlanders' reservations, the Danish authorities decided to include it in the Communities anyway, in the country's Treaty of Accession, signed in 1972 and in force since 1973. This was not the case with the Faroe Islands, which already had a statute of autonomy at the time, and thus never joined the Communities.

Years later, Greenland also obtained a statute of autonomy within the context of the Danish state, which transferred to it nearly all the powers exercised to date by the Danish authorities 
and entered into force on I May 1979. Based on the statute, the Greenland Parliament decided, in 198I, to hold a "non-binding referendum" on continued membership in the EC. The referendum was held on 23 February 1982, and the majority ( $52 \%$ vs $46.1 \%$ ) voted in favour of Greenland's exit from the Community. The Danish government - as the competent authority to do so - submitted a memorandum to the EC Council of Ministers, proposing amendments to the Treaties. Denmark submitted the inclusion of Greenland to the list of OCTs (Annex IV of the EEC Treaty) and negotiated an agreement with three similar articles for the three treaties (EEC, ECSC, EAEC), providing that "This Treaty shall not apply to Greenland", together with other modifications. This situation changed again in 2008, when Greenlanders voted in favour of greater autonomy, which was achieved through the passage of the Home Rule Act of 2I June 2009, another step towards greater self-government. The territory is home to a large independence movement, represented by most of the political parties (except the conservative party), which advocate secession from Denmark.

Although from a constitutional point of view, the independence of the Faroe Islands and Greenland is possible, the fact of the matter is that the Danish authorities have reacted swiftly and decisively whenever such possibilities might have occurred, demanding that the option be supported by a sufficiently representative percentage of the population, which, to date, has not been the case.

\section{(e) Territories Belonging to Portugal}

The Azores are an archipelago located in the North Atlantic, about 1,500 km west of Lisbon and 3,600 km east of North America. They have a surface area of $2,322 \mathrm{~km}^{2}$ and a population of 245,766 inhabitants. Since 1976, the Azores have been an autonomous region of Portugal. As such, they have their own regional government and parliament, elected by direct universal suffrage and with broad legislative and political powers. The seat of the regional government is in Ponta Delgada (São Miguel), and that of the parliament, in Horta (Faial).

Madeira is an Atlantic archipelago located $900 \mathrm{~km}$ southwest of Portugal (1,000 km from Lisbon) and $550 \mathrm{~km}$ west of the African coast (Agadir). It has a surface area of $801.52 \mathrm{~km}^{2}$ and a population of 256,424 inhabitants. Since 1976, Madeira has also been an autonomous region of the Republic of Portugal. It is governed by a specific political and administrative regime: the statute of an autonomous region. It has its own governing bodies: a legislative assembly and a regional government. The seat of the regional government is in Funchal.

Portugal is a unitary and centralized state, of which its overseas territories are an integral part. However, the Azores and Madeira have a status that sharply differentiates them from the metropolitan territory. Under the Portuguese Constitution, they are "autonomous regions", a status that affords them broad internal autonomy, in terms of both legislative and executive 
powers (Article 6). Beyond that, the Portuguese Constitution does not provide for the separation of the constituent territories of the Republic.

\section{(f) Territories Belonging to Spain}

The Canary Islands are an Atlantic archipelago made up of seven islands, located northwest of the Sahara and 2,000 km from Madrid. They have a surface area of 7,447 $\mathrm{km}^{2}$ and a population of 2,135,722 inhabitants. The Canary Islands are part of the Spanish system of self-governing regions or "autonomous communities" (comunidades autónomas) within a parliamentary monarchy defined in the 1978 Constitution. They have their own regional government and a parliament consisting of 60 seats. They are divided into two provinces: Las Palmas and Santa Cruz de Tenerife.

The Spanish Constitution likewise does not contain support for unilateral procedures of independence. On the contrary, it makes express mention of the territorial integrity of the state and its indivisibility (Article 2). It additionally provides for a mechanism for forcing an autonomous community to comply with its constitutional obligations in extreme cases of breach or of serious harm to the general interests of Spain (Article 155).

(B) INVOCATION OF THE PRINCIPLE OF SELF-DETERMINATION OF PEOPLES IN TERRITORIES WITH SPECIAL STATUS

In view of the diversity of the overseas territories' situations, the EU has always maintained the same position, namely, that they are, as noted, internal questions and processes of its Member States. It is the Member States who are firstly and primarily responsible for the economic and social development of their respective overseas territories. They also have the power to establish or modify the political and administrative links that they have with these entities, in accordance with their constitutional systems. Of course, in so doing, they must bear in mind the undergirding values of the process of European integration, set out in Article 2 TFEU, as well as the provisions of international law applicable to such relations, in particular, those referring to non-self-governing territories and decolonization processes.

With regard to the latter, it should be recalled that on I4 December 1960, UN General Assembly Resolution $15 \mathrm{I} 4(\mathrm{XV})$ paved the way for the decolonization of dozens of territories. The Declaration on the Granting of Independence to Colonial Countries and Peoples provided that all peoples have the right to self-determination. It further proclaimed the need to bring colonialism "to a speedy and unconditional end". Two years later, the UN created the Special Committee on Decolonization and, although 80 former colonies have since achieved independence, I7 territories have yet to be decolonized. Most of them continue to have specific relations with certain Member States of the European Union and have a special status within it. This is the case of: Anguilla; Bermuda; Gibraltar; the Cayman Islands; the Falkland Islands; 
the Turks and Caicos Islands; the British Virgin Islands; Montserrat; New Caledonia; French Polynesia; Pitcairn; and Saint Helena.

Some of these territories have been on the Special Committee's list since its creation; others were added only recently, such as French Polynesia (2013); and still others, such as the Turks and Caicos Islands, remain on the list even though the respective metropolis granted them independence, because they renounced it. In addition to this, there is the peculiar situation of Gibraltar, which, in the wake of the new 2006 Constitution and the subsequent referendum, considers that the circumstances for its removal from the list have been met, although this claim has not yet been acknowledged by the UN.

To be removed from the list, the territory in question has to: achieve independence, fully join the country on which it depends, or become a free state associated with it. To this end, it must be given the opportunity to decide, with guarantees, on the type of relations it wishes to maintain with the parent state. Indeed, plebiscites and referenda have already been held on this question in both OCTs and other territories with special status, such as Anguilla, Bermuda, the Turks and Caicos Islands, the New Caledonia, or, most controversially, Gibraltar and the Falkland Islands. With regard to all these situations, it is worth recalling that the UN General Assembly is responsible for the decision to remove a non-self-governing country from the list of territories subjected to the process of decolonization, not the administering power or the administered territory itself.

Moreover, the list does not include all the ORs and overseas territories, in which issues of autonomy, assimilation or independence have been raised with varying degrees of intensity. In some cases, the population of these regions and territories has furthermore already been asked to vote on the type of link it wishes to maintain with the parent state (Mayotte, Wallis and Futuna, Anguilla, Bermuda, Guadeloupe, Martinique, etc.). Additionally, the evolution, in recent years, of the political, economic and social situation of some of these entities has generated debate and tensions, both in the metropolises and in the affected regions and territories themselves. They have seen calls for more autonomous development and even full independence, based on the principle of self-determination. Of course, there are also movements advocating the fullest possible assimilation with the respective metropolis.

(I) Assimilationist, Autonomist and Separatist Movements in the Territories with Special Status

(a) In the French Overseas Territories

The popularity of nationalist movements in these enclaves has fluctuated. After gaining strength in the 1970s and 1980 s, their influence seems to have declined at the turn of the $2 \mathrm{I}^{\mathrm{st}}$ century. There are currently no major independence movements in France's Latin American 
territories. ${ }^{26}$ There used to be one in Guiana, especially in the 1970s, and another in Guadeloupe, also in that decade. In Martinique, they have always been present, but support for them is limited and remains level. All of these territories have political parties and leaders who advocate these goals, some of whom, such as the Martinican Alfred Marie-Jeanne, have played, and continue to play, a prominent political role. However, the fact of the matter is that whenever the question has been put to a vote, the people, as will be seen, have come out against increased autonomy from France.

Sometimes, social conflicts are confounded with political ones. Such situations can give rise to autonomist or separatist trends. However, in general, the peoples of these territories seek greater involvement by the metropolis in the economic and social development of their regions and more proactive policies to combat illegal immigration and insecurity. In the social sphere, the lack of economic prospects has resulted in episodes of unrest and conflict in recent years in the DROMs. For instance, in 2009, the French Caribbean was rocked by a general strike to protest low wages and the scarcity and high prices of basic commodities. It began in the Guadeloupe archipelago and soon spread to neighbouring Martinique. The strike took place in a context in which the economic crisis in Europe had led to a dramatic decline in tourism, the main source of revenue for the Caribbean islands, resulting in an unsustainable situation. After a month of paralysis and riots that led the metropolis to send police reinforcements to the islands, the French government agreed to increase wages and meet the Caribbean population's main demands. The recent riots in French Guiana have once again exposed a problem involving the overseas population. On 25 March 2017, a general strike was called, spurred on by the Guianese unions and a group calling itself the 500 Brothers. The aim was to denounce the situation of marginalization in which the territory was maintained by the metropolis, which, according to the strikers, invested a disproportionate amount of money in the space centre whose activity accounts for $15 \%$ of the Guianese GDP - but little in the rest of the territory. They also called for increased law enforcement, as well as other social improvements. ${ }^{27}$ Ultimately, the French government agreed to sign the Guiana Agreement, undertaking to invest heavily in the underfunded areas.

Similar situations have occurred multiple times on Réunion. Here, too, the reason was the high cost of living with respect to wages and the resulting precariousness. This territory is home to a more autonomist than separatist movement, initially formed around the Communist Party of Réunion (Parti Communiste Réunionnais or PCR), founded in 1962. In 1978, the UN

26 A.-P. Blérald, La Question nationale en Guadeloupe et en Martinique (L'Harmattan, Paris, 1988).

${ }_{27}$ For the 27 days that the strike lasted, riots swept Guiana, which was left completely isolated: the space centre was occupied, delaying the launch of two European satellites, and access to both the airport and port was blocked. 
came out in favour of the island's full independence, thereby internationalizing the debate. In 1979, in the elections to the European Parliament, Paul Vergés, leader of the PCR, laid out his thesis of bicolonialism, denouncing that, in addition to being dominated by France, Réunion was also subject to the interests of the EC. In 1980, Jean-Baptiste Ponama, a regional figure, founded the Movement for the Independence of Réunion (Mouvement pour l'indépendance de la Réunion or MIR). In 1992, Camille Sudre, who advocated greater home rule, won the regional elections, with the support of the PCR. The French courts annulled the elections due to alleged irregularities and prohibited Sudre from standing again. In the regional elections of 1993, the "Free-DOM list", led by his wife, Marguerite Sudre, won. More recently, in the last two decades, the more openly separatist movements have coalesced around the Popular Front for National Liberation (Lorganizasion Popilèr po libèr nout Péi or LPLP), whose demands have been echoed by the African Union. It also advocates the island's inclusion on the UN's list of nonself-governing territories. On 5 November 2017, this party proclaimed not independence, but rather the existence of the State of Réunion. The declaration had virtually no impact.

Nor has neighbouring Mayotte been free of conflict. This small island decided to remain a part of France in 1976 and, in 20II, it became a department and region..$^{28}$ It has been the poorest one ever since. In April 2016, the island was paralysed by a general strike under the slogan "Real Equality", causing riots that lasted two weeks. The islanders' main demands were equal labour rights to those in the metropolis, greater social benefits and improved public infrastructures in the spheres of energy, education and healthcare. The Overseas Ministry was ultimately forced to reach an agreement with the main unions. However, the agreement has not managed to dispel the social unrest completely. Social tensions persist, aggravated by uncontrolled immigration, particularly from the neighbouring Comoro Islands, a country that continues to claim sovereignty over Mayotte.

Such tensions also occurred in French Polynesia. A French protectorate since 1842 and a colony since 1880 , it became an overseas territory in 1946 and, in 2003, an overseas collectivity. ${ }^{29}$ Since 2004, it has had a status of reinforced autonomy. It has a democratically elected parliament and an autonomous government that administers public affairs. Its citizens are French citizens. For decades, autonomist, separatist and assimilationist or unionist movements have competed for the country's future.

28 G. Ciavarini, Mayotte et l'Union Européenne: entre PTOM et RUP, (European Commission, Brussels, 20 July 2004).

29 French Polynesia, located $18,000 \mathrm{~km}$ from Europe, spans a vast marine zone in the South Pacific with an area comparable to Europe's $\left(5.5\right.$ million $\mathrm{km}^{2}$ ). It has $\mathrm{II} 8$ inhabited islands, comprising $3,600 \mathrm{~km}^{2}$ of dry land, grouped into five archipelagos: the Society Islands, the Marquesas Islands, the Gambier Islands, the Austral Islands, and the Tuamotu Islands. J.-Y. Faberon (ed.), Destin des collectivités politiques d'Océanie (Ed. Presses Universitaires d'Aix-Marseille, Aix-en-Provence, 20II). 
The first nationalist movement took shape with the founding, by Pouvanaa Oopa in 1947, of the Democratic Rally of the Tahitian People (Rassemblement démocratique des populations tahitiennes or RDPT), which, although it did not openly call for independence, did support greater self-government and the fight against capitalism. The RDPT was dissolved in 1963, but it re-emerged in 1965 as Pupu Here Aia, led by John Teariki. These movements were strengthened by the decision by General de Gaulle, in 196I, to locate a Pacific (Nuclear) Test Centre in the territory. This policy was continued during his successor Pompidou's presidency and remained unchanged until 1977, when, under President Giscard d'Estaing, a series of events, including a serious crisis (1976) and Oopa's death (1977), prompted a change. On the political front, the rig7os were marked by the emergence of independence movements, in particular, the socialist Mana Te Nunaa, founded in 1975 by Jacques Drollet, and the FLP-Tavini Huiraatira, founded in 1977 by Oscar Temaru. Within the autonomist current, Jean Juventin, mayor of Papeete in 1977, played a prominent role as the leader of Pupu Here Aia after the death of Teariki (1983). Attention should also be called to the Te Ea Api division, whose secretary general, Émile Vernaudon, founded the Aia Api party in 1982. In 1977, the Tahitian Union became Tahoeraa Huiraatira (Popular Rally) within the framework of the RPR. This party then evolved towards autonomist positions. In 2004, UPLD was formed, a pro-independence coalition dominated by Temaru's Tavini Huiraatira. Ever since, it has been the main Polynesian separatist party, establishing itself as an important political force in French Polynesia. It developed a nationalist ideology with the ultimate goal of fostering the territory's political evolution out of the French Republic and replacing French Polynesia with an independent state, to be called Tahiti Nui (Big Tahiti).30 In 2013, Temaru, the French Polynesian separatist leader, and his closest advisors achieved the territory's re-inclusion on the UN's list of non-selfgoverning territories. Since then, pro-independence representatives have been travelling regularly to New York to attend various committee meetings and advance their cause: sovereignty and decolonization of French Polynesia. ${ }^{31}$ On 17 March 2017, France and French Polynesia signed an agreement, whereby, in addition to a commitment to address the consequences of the nuclear tests, the French government agreed to work with the European institutions to improve the association regime, support Polynesia's integration in its regional environment, and increase funding.

In general, this territory is home to two opposing trends: a unionist movement, and a movement advocating self-determination, although not necessarily independence, but rather

30 On these questions, see: S. Al Wardi, Tabiti Nui ou les dérives de l'autonomie (Ed. L'Harmattan, Paris, 2008).

${ }^{3 I}$ In this order of things, mention should be made of the claim that the separatist party, Tavini Huiraatira, seeks to bring before the International Court of Justice for "violation of the nuclear non-proliferation agreement" by France, which would be joined or parallel to that filed by the Marshall Islands in 2014. 
greater and deeper autonomy. Indeed, that is the option that has received the strongest support at the polls.3.

New Caledonia, which lies some 16,000 km away from the metropolis, has been French since I853. In 1946, it became a French overseas territory, but the local self-government that it was granted favoured the population of European origin. This situation was exacerbated in 1962 by the independence of Algeria and the ensuing influx to the islands of (largely ultranationalist) pieds noirs. In 1970, the native population led a series of strikes and occupations. The emergence of independent countries such as Samoa, Fiji or Tonga, coupled with the rejection of Gaullist centralism, gave rise to a pro-independence movement. In 1975, the Party of Kanak Liberation, or Palika, was founded and, later, the Independence Front (Front Indépendantiste), a coalition of parties and movements formed with the goal of winning the territorial elections. The following decade, it was reconstituted as the Kanak Socialist National Liberation Front (Front de Libération Nationale Kanake et Socialiste or FLNKS).

In the 1980 s, tensions erupted between the Kanak and European communities. In 1984, the National Assembly legislated a special framework for self-government, but rejected proindependence amendments. This led to elections and a referendum. However, the FLNKS claimed that the electoral roll favoured the metropolis. It called upon people to boycott the referendum and proclaim independence, whilst at the same time creating a "provisional government" to force secession. This, in turn, led to "les évènements", four years of riots and political conflicts with both the metropolis and the unionists. The upheaval culminated in the taking of hostages on the island of Uvea, where 4 gendarmes were killed and 27 held hostage. Paris reacted with Operation Victor, which freed the hostages; 19 separatists and 2 soldiers were killed. The action shone a spotlight on the New Caledonian conflict, which was verging on civil war, and the need to find a solution. On 26 June 1988, the Matignon-Oudinot Agreements were signed. Under the historic agreements, economic and social improvements would be made for the Kanak community over a period of ten years, during which time no independence referendum would be called. The agreements were approved by French voters in a referendum held on 6 November 1988, although turnout was low. Ten years later, on 5 May 1998, the Nouméa Accord was signed, establishing a progressive decolonization. The Accord provided for the transfer of certain powers from France to New Caledonia in many areas, except defence, security, the judiciary, the currency and external relations. The Accord further provided for a referendum on New Caledonia's accession to full sovereignty, to be held no earlier than 2014 and no later than 2019. In case of a negative vote, a second and, possibly, a third referendum could be held. After two negative votes, a new agreement would be negotiated.

32 In the territorial elections of March 2013, 70\% of the vote went to autonomist parties, awarding them 47 of the 57 seats vs io for pro-independence parties. 
In the meantime, the Nouméa Accord facilitated the transfers that would ensure "near sovereignty" within 15 or 20 years. The French Constitution was amended and, as seen, Title XIII ("Transitional Provisions Pertaining to New Caledonia") was added. The new Title grants the territory a form of organization adapted to its own identity, constituting an original model, created to define the distribution of sovereignty with France. Its citizens are French citizens. It is thus an overseas collectivity with a special status, which benefits in particular from a certain political autonomy. Since 1988, it has been divided into three provinces with representatives in Congress. The role of this assembly is mainly to appoint the members of the government of New Caledonia. The president represents the archipelago and heads the government. The French state is represented by the High Commissioner of the Republic, whose role is similar to that of the Prefects. Since 1988, New Caledonia has also had a traditional Senate, which is the guardian and champion of the Kanak identity.

The presence of autonomist and separatist movements in France's overseas departments, collectivities and territories has not displaced other approaches, more aimed at assimilation or integration with the metropolis. In general, there is no real will to separate from metropolitan France, as the revenue that these territories receive in the form of contributions from the state is quite substantial and allows them to maintain their hegemony over other independent islands, such as Haiti, Vanuatu or the Comoros. In the view of much of the population of the French overseas territories, these islands are examples of other former colonies in which independence has led to misery, poverty, violence, mafias, political instability, etc. This would suggest that, in these territories, including those, such as New Caledonia or French Polynesia, in which the separatist processes are farthest along, most of the population does not see independence as a real solution, at least in the short or medium term.

\section{(b) In the British Overseas Territories}

Very diverse situations can be found in the British Overseas Territories. The Caribbean territories, consisting of islands and archipelagos, are home to pro-independence movements that seek to continue the emancipation movement that, since the 1960s, has separated many territories in the region from the United Kingdom. Some of the leaders and parties support independence, as in Anguilla, others seek greater autonomy, as in the Virgin Islands, and in one case they even advocate for secession from the United Kingdom and association with Canada (Turks and Caicos Islands). However, as the various plebiscites and elections held in these territories show, in general, the popular support for these movements and leaders is on the wane, and the inhabitants of the territories wish to maintain the current status quo. There are multiple reasons for this. In the author's view, one of the most powerful has been the transformation of many of these territories into tax havens. 
In the case of Anguilla, various events led to its secession from Saint Kitts and Nevis in 1967, resulting in a de facto independence, which, in turn, led to the intervention of the British armed forces in 1969 to regain control. In 1971, the United Kingdom increased the island's autonomy, approving a Constitution that established a parliamentary government and created the position of "Governor" — appointed by the British Crown - responsible for defence, external affairs, internal security, public services, the judiciary and the audit office. In Bermuda, the Progressive Labour Party represents the political current in favour of independence from the United Kingdom, although it lacks widespread popular support. In the 1995 referendum, the independence option was defeated by a considerable margin ( $74 \%$ of the population voted against it). However, the Bermuda Industrial Union and the Progressive Labour Party (then in the opposition) had called for a boycott of the referendum, which had an unquantified impact on the result. Currently, opponents of independence are the majority; the population values financial security above all else. This is because, unlike other islands, Bermudians have a high standard of living, pay no income tax, and do not bear the cost of their external representation. A similar case can be found in the Cayman Islands, which, in 1972, were granted broad autonomy in internal matters by a new Constitution, and which, also like the others, are exempted from taxes, making them a profitable financial enclave. 33

Montserrat has been governed by an administrator appointed by the United Kingdom since 1960. In the 1973 elections, the People's Liberation Movement gained strength, and, in 1979, the new Chief Minister, John Osborne, announced independence for 1982. Opponents of independence refused, arguing that tourism and remittances would not cover the balance of trade deficit — which was assumed by the United Kingdom. The independence never arrived. In addition, the problems continued. In 1995 and 1996, the volcanic eruptions of Chances Peak wreaked havoc on the economy. Thousands of people were evacuated, and the Chief Minister, David Brandt, called for an investigation into the British attitude of depopulating Montserrat rather than aiding those who wished to stay there. In early 2002, London passed legislation granting British citizenship to its dependencies. Many inhabitants of Montserrat took advantage to emigrate, further decreasing the chances of independence.

The Turks and Caicos Islands were administered from the Bahamas until i848. In I874, they were annexed to Jamaica, which became independent in 1962. In 1972, the islands received their own Governor, and the 1976 Constitution granted them home rule and established a Legislative

\footnotetext{
33 In 1987, 515 banks were registered there. In 1996, the capture of Mexican drug traffickers exposed the involvement of the islands' banking system in major money laundering operations. According to an analysis by Tax Justice Network —endorsed by scholars, activists and NGOs - Switzerland, the Cayman Islands and Luxembourg occupied the podium in 2010 for the most active "opaque jurisdictions". This opacity is very profitable for them: their economy is one of the soundest in the Caribbean, and of the 40,000 companies registered in their territory, nearly 700 are banks and foundations that handle billions of euros and dollars.
} 
Council, Executive Council, Supreme Court and Court of Appeals. On this island, too, drug trafficking and money laundering caused serious problems. Norman Saunders, the former Chief Minister, in office since 1980, and his Development Minister, Stafford Missick, were arrested in Miami, in 1985, when they were trying to create an international drug trafficking ring using the islands as a bridge between the US and South America. London responded by suspending the territory's constitutional government and assuming direct control until general elections, held in 1988, restored a certain level of self-government to the islands.

Finally, in 1872 , the British Virgin Islands were incorporated into the British colony of the Leeward Islands, which was administered under a federal system. Although the federation was dissolved in July 1956, they remained under their control until 1960, when they became an independent territory, with an Administrator appointed by the crown. In 1977, the Constitution was amended to increase the self-government, but the responsibility for defence, internal security and external relations remained in British hands. The islands followed the usual trend for these overseas territories: they are a tax haven, which, more than once, has been suspected of receiving revenue from drug trafficking.

In addition to these territories, the UN's list of non-self-governing territories includes other British Overseas Territories. Although differentiated, for the purposes of the present study, they can be characterized by the fact that they are disputed by the UK and other countries (namely, Argentina and Spain) and by the fact that their current population is the result of British colonization. These territories are the Falkland Islands and Gibraltar. Because of the composition of their populations, they are not home to separatist movements, but rather integrationists seeking greater assimilation with the UK. However, these processes are covered by the British government's statement of respect for the right of self-determination of the territories' inhabitants.

The Falkland Islands, an archipelago some 400 nautical miles off the Argentine coast, was not historically settled. It was occupied by the British in 1833 , when only three dozen people inhabited the islands. After World War II, the UN's Committee on Decolonization included the islands amongst the non-self-governing territories but established that, in their case, the principle of self-determination did not apply, because the inhabitants were British and, thus, dependent on the metropolis. The British government, however, considers that it promotes the islanders' right to self-determination. In 2009, a new Constitution came into force granting the local population the right to self-government in all areas except defence and external affairs. On Io and Ir March 20I3, the inhabitants of the archipelago voted to remain a "British overseas territory”. The UN was not involved in the vote. In any case, it is highly doubtful that the inhabitants of the islands constitute a people with the right to self-determination, as reflected in more than 40 resolutions of the UN General Assembly and the Committee on 
Decolonization, in particular, Resolution 40/2I of 27 November 1985, in which the General Assembly rejected this possibility outright.

Briefly, the situation of the other contested territory, disputed by Spain and the United Kingdom, is similar. Gibraltar is a British overseas territory with broad self-government. It had been part of Castile since the second half of the $15^{\text {th }}$ century. However, in 1704 , the Rock was occupied by the Anglo-Dutch squadron that supported Charles III in the War of the Spanish Succession. It was ultimately ceded under the Treaty of Utrecht in 1713 , although the area of the isthmus was illegally occupied by the British and maintained to the present day. The occupation of Gibraltar entailed the displacement of most of its population and their replacement by a population subsequently implanted by the United Kingdom. Spain has tried to recover it, but the local population is opposed. In 1967, a plebiscite supported colonial dependence; only 44 of the 12,757 voters voted for accession to Spain. In 1969, a new Constitution reaffirmed the English link, transferring internal affairs to an executive to be elected by the Gibraltarians whilst reserving external affairs and defence for the Crown. Spain closed its borders until 1985. In 2002, 99\% of voters came out against shared sovereignty in another plebiscite not recognized by the UN. And, in 2006, a new Constitution was adopted, accepted by the population in a referendum. It does not mention the principle of selfdetermination, nor is there any reduction in British sovereignty over Gibraltar: the UK retains full international responsibility for the territory. Its economy has been based on services to the British Defence Ministry, although, since 1988, tax legislation -making it VAT free and placing it outside the customs union— has been passed making it a controversial tax haven and offshore financial centre with no small share of controversy.

Finally, there are Saint Helena, Ascension and Tristan da Cunha, British island territories in the South Atlantic. They have their own executive and legislative bodies, although they are subordinated to Governors appointed by the metropolis. In December of 1984, the UN General Assembly, with the opposing votes of London and Washington, urged Great Britain to bolster the islands' economy - based on the fisheries industry, crafts and forestry - and raise awareness amongst the inhabitants of their right to become independent. It also challenged the presence of a military base, as they are prohibited in non-self-governing territories. ${ }^{34}$ In January 1989, a Constitution came into force that granted more powers to the local assembly of Saint Helena.

\section{(c) In the Dutch Overseas Territories}

In Curaçao, which, since 20I0, has been an autonomous country within the Kingdom of the Netherlands, there is a strong pro-independence movement, whose main spokesperson is the

34 R. Bissio (dir.), Guía del mundo 1999-2000. El mundo visto desde el sur (Instituto del Tercer Mundo, Montevideo, 2000), at 507. 
Sovereign People party, which has a significant presence in the territory's institutions and share of votes in the parliamentary elections. From the incidents of 1969 until the more recent events of 2017, the territory has experienced situations of tension and violence that have led the Dutch government to reinforce its military presence there in order to restore public order. The Dutch government found the legal formula to intervene in the island in Articles 43 and 51 of the Charter for the Kingdom of the Netherlands (1954), the document governing the relations of Curaçao, Aruba and Sint Maarten with the metropolis. According to these provisions, the safeguarding of rights, freedoms, legal certainty and good governance are an affair of the realm, which may act whenever a local body flouts the law. On 3 April, the Netherlands gave full powers to the Governor to hold elections. It did so through a rule drafted by the Minister of the Interior and signed by the King. It was the Hague's most emphatic intervention in one of its former colonies since they had attained the status of independent countries.

The case of the Netherlands Antilles poses the paradox of a parent state that is willing, even clearly determined, to grant independence to territories that, in contrast, do not want it.

\section{(d) In the Portuguese and Spanish ORs}

Both of the Portuguese ORs, the Azores and Madeira, are home to low-grade pro-independence movements. These movements reached their peak activity in the 1970s, when democracy was restored in Portugal. In Madeira, the most active movement was the Madeira Archipelago Liberation Front (Frente de Libertação do Arquipélago da Madeira or FLAMA), founded in 1974, which carried out various armed actions from 1974 to 1976 . The same years also saw the emergence of the Azores Liberation Front movement in the Azores, which called for the archipelago's independence. Neither of these movements is represented in the parliaments of either of the Portuguese autonomous regions. Furthermore, Portuguese law prohibits these types of movements and parties, insofar as Article 9 of the Law on Political Parties (Organic Law 2/2003, 22 August 2003) provides that "the formation of political parties that, through their name or programme objectives, are of a regional nature or scope is not permitted". In short, the establishment of democracy in the country considerably reduced pro-independence sentiment, transforming it into a drive towards increased autonomy.

With regard to the Canary Islands, which have had a Statute of Autonomy since 1982, various federalist, autonomist and separatist movements have co-existed in the archipelago since the late $19^{\text {th }}$ century. The early $20^{\text {th }}$ century saw the emergence of the Autonomist People's Party (Partido Popular Autonomista), which spoke of a "colonial reality". In the 1920s, the Canarian Nationalist Party (Partido Nacionalista Canario) was founded. It was eventually dissolved and, in the 1980s, gave rise to the Canarian Coalition (Coalicion Canaria) party, which has a significant presence in the autonomous community's government. In 1964, the Movement for the Self-Determination and Independence of the Canary Archipelago (Movimiento Por la 
Autodeterminación e Independencia del Archipiélago Canario or MPAIAC) was founded in Algeria. This radical group espoused armed struggle. Its leader, Antonio Cubillo, would become one of the preeminent figures of Canarian nationalism. Following his expulsion from the Movement, he went on to found the National Congress of the Canary Islands (Congreso Nacional de Canarias or CNC). These movements have experienced tensions and internal schisms and, in many cases, their current activity is negligible or non-existent. Today, many organizations and political parties describe themselves as nationalists, although not all of them support the independence of the Canary Islands. ${ }^{35}$ As for the Spanish Constitution of 1978 , as noted, any unilateral process of independence can be ruled out, since national sovereignty is vested in the Spanish people (Article 1.2) and based on the indissoluble unity of the Spanish Nation, the common and indivisible homeland of all Spaniards (Art. 2).

(2) Plebiscites and Referenda in Special-Status Territories

As seen thus far, many of the territories with special status in the EU have held one or more plebiscites throughout their history on the links their people would like to have with the Member States on which they depend. There are also other outstanding processes that are not yet over.

\section{(a) The Self-Determination Referendum in New Caledonia}

As noted, the UN's Special Committee on Decolonization includes New Caledonia on its list of non-self-governing countries. One way to be removed from this list is to hold a referendum, with sufficient guarantees, for the people of the territory to decide on their future. In this regard, in November 2017, the French government and representatives of New Caledonia reached a political compromise, in the context of the Nouméa Accord, to work out the details of a referendum on self-determination, to be held by November 20I8. It will not be the first time the territory has held a referendum on its future. It did so in 1987 , when, following a boycott by the pro-independence forces, the "No" campaign won, with $98 \%$ of the vote.

The Nouméa Accord launched a process of "progressive decolonization", which is to culminate in a referendum on whether or not the territorial collectivity should remain within France, i.e. on the transfer to New Caledonia of sovereign powers, access to a full international status, and the transformation of citizenship into a nationality. First, the New Caledonian Congress had to set the date of the referendum; otherwise, it would fall to the French government to do so. In this regard, on I9 March 2018, the New Caledonian Congress decided,

35 In this regard, in the successive regional elections, the ceiling of votes for openly pro-independence parties has been less than 10,000, whilst the autonomist parties have garnered more than 160,000 votes, and national parties more than 350,000 . 
by 38 votes to 14 , on 4 November 2018 as the date for the referendum. The exact question to be put to vote still had to be decided, a matter fraught with tension and controversy of its own.

Calling the referendum has been a delicate mission due to the strong tensions that persist between the communities. The Kanaks, the indigenous Melanesian inhabitants, account for a bit more than $40 \%$ of the population. Europeans, especially the French, pejoratively called "Caldoches", make up slightly less than a third of the islands' 270,000 inhabitants. Then there are other communities and a fairly large interethnic population. The racial melting pot is thus complex, and it is difficult to determine the exact ethnic breakdown. Hence, one of the thorniest issues is the electoral roll. The first hurtle to be overcome is for the Kanaka aborigines and the Caldoche population to reach an agreement on it. To this end, the French and Caledonian authorities agreed to register II,000 more people on the electoral role for the referendum, one of the most controversial points. They have also specified the polling stations to be used for the referendum, the presence of international observers, and the proxy vote. The electoral rolls are limited to people who have resided in the territory uninterruptedly since 1994, although there are discrepancies over whether or not those born on the island should be registered..$^{6}$

On 28 March 20r8, the French government unveiled the question that voters will be asked in the referendum to the territory's political parties at a meeting in Paris following the related talks. It will be worded as follows: "Do you want New Caledonia to accede to full sovereignty and become independent?" This wording will be submitted to the Council of State for approval. The pro-independence camp wanted the question to refer to "full sovereignty" rather than independence, whilst the right-wing groups that advocate ties to France wanted to pose a choice between "independence" and "remaining in France".

Most surveys have shown that a majority of the inhabitants want to maintain the archipelago's links to the French metropolis, as the current situation affords them almost complete autonomy in the management of their affairs, except for sovereign powers, and moreover allows them to receive various types of solidarity funds from France. This opinion has taken shape in the so-called "loyalist" view, based on opposition to losing the French identity and, especially, on the fear that New Caledonia will become a sort of Vanuatu or Papua

36 The pro-independence parties have sought to allow only Kanaks to vote in the referendum, but the coalition government has dismissed the proposal in favour of allowing all residents of the island to vote, which would benefit its position. The French Supreme Court found that only registered residents of New Caledonia since 1998 or those who could offer proof that they had lived there since 1988 could vote. It thus ruled, as noted above, in favour of the loyalists. Both the FLNKS and the other pro-independence parties have denounced that this way of preparing the electoral roll is harmful to their interests. On the other hand, giving the vote, as they proposed, only to ethnic Kanaka would be a major triumph for the pro-independence cause. Compounding the matter, the latter have denounced that more than 6,000 people voted irregularly in the 2014 elections, since, according to them, the provisions agreed by the Supreme Court were not respected. 
New Guinea, countries that, in this faction's view, have become impoverished since their emancipation. In addition, they cite the considerable financial support that the metropolis gives to New Caledonia (close to one billion dollars a year), especially since the Nouméa Accord, and the protective role it plays, in particular against China, which, as the world's largest importer of nickel, regards the islands as a future satellite country. In contrast, the Kanaks mostly support secession. Their argument is mainly based on the danger that the demographic balance could tip in favour of non-native ethnicities and that the metropolis could withdraw its economic support in the near future, causing the local financial system to collapse.

The independence referendum was held on 4 November 2018. The result was $56.4 \%$ not favourable to independence and $43.6 \%$ in favour to independence. The turnout was $81 \%$ of the 174.995 voters eligible to vote. However, the Nouméa Accord provides for the possibility of holding up to two more referenda if the result is unfavourable to independence. Faced with the stagnation of the situation, which could drag on for more than ten years, the French authorities are tabling alternative proposals. The first would be the creation of an associated state, similar to the relationship that, in the region, links the Cook Islands and the Federated States of Micronesia to New Zealand and the United States, respectively. In this regard, Article 88 of the French Constitution authorizes France to enter into agreements with states that wish to associate with it. The second option would be the creation of a federated state, which would make it possible to meet the demands of both parties: a state for those who want independence and maintenance within the Republic for those who do not. This path would require amendment of the constitution to create a federal link between the Republic and only one of its territories, establishing an uncommonly original asymmetric federalism with no equivalent in the rest of the world.

(b) Other Plebiscites Resulting in Greater Assimilation, Reinforced Autonomy or a Step towards Independence

Virtually all overseas territories that have special status in the EU have held plebiscites on the future of their relations with the parent states. In general, the results have been favourable to greater integration with the metropolis, to a lesser extent to increased autonomy, and, exceptionally, to independence.

Thus, in the French overseas territories, supporters of assimilation with metropolitan France have won the majority of referenda and plebiscites that have been held. This is what happened in French Guiana, Martinique and Guadeloupe. In the latter, a 2003 referendum asked Guadeloupeans whether they wanted the island to become a territorial collectivity, which would have given the regional government greater autonomy. The proposal was rejected by $73 \%$ of the voters. In simultaneous referenda, Saint Martin and Saint Barthélemy voted to become territorial collectivities, separating themselves administratively and politically from 
Guadeloupe. With regard to French Guiana and Martinique, simultaneous referenda were held on Io January 2010 on a potential change in the territories' political-administrative status within the French Republic. The question was similar: Do you approve of the territory's transformation into an overseas collectivity governed by Article 74 of the Constitution, endowed with a particular form of organization that takes into account its own interests with due regard for the general interest of the Republic? In the case of Guiana, $69.8 \%$ of voters rejected the proposal for greater autonomy. In the case of Martinique, $79.31 \%$ of voters did.

Developments in Mayotte have been very particular. In 1974, in an independence referendum in the Comoros, $96 \%$ of the inhabitants of the islands of Grande Comore, Anjouan and Mohéli voted for independence, whilst $64 \%$ of the inhabitants of Mayotte voted to remain in the French Republic. In 1975, the Comoro Islands formed a new independent state, with the exception of Mayotte, which remained French. In a second local referendum held in Mayotte on 8 February 1976, 99.4\% of voters voted to remain in France. In March 2009, another referendum was held in Mayotte on its accession to the status of French department. The "Yes" vote won, making it, as already noted, the $\mathrm{IOI}^{\text {st }}$ French department.

The case of Wallis and Futuna dates back further. In 1961, the South Pacific archipelago voted to remain an overseas territory within the French Republic.

With regard to the British Overseas Territories, there is a clear difference between the plebiscites held in the Falkland Islands and Gibraltar and those held in the other territories. A pro-independence outcome was highly unlikely in the referenda held in the Falkland Islands in $2013^{37}$ and Gibraltar in $2006,3^{38}$ given the make-up of their populations (implanted by the administering power) and the surrounding international context (claims by Argentina and Spain, respectively). These were plebiscites that had little to do with the referenda conducted under UN supervision, and contravened numerous General Assembly resolutions on the matter. Instead, they were local plebiscites held within the British political-administrative framework for the purpose of adapting the constitutional relations between the territories and the United Kingdom, by, amongst other things, granting them a greater degree of autonomy and grounding them under the British Overseas Territory Act.

37 1,672 people were entitled to vote, 155 of whom (9.2\%) did not. Of those who did, 1,513 voted for the islands to continue to be administered by the British government ( $99.83 \%$ of the votes), whilst 3 people ( $0.17 \%$ of the votes) voted for a change in the status quo. However, the latter vote cannot be interpreted as endorsing a single option, since the change might refer to a call for full independence, restoration of the sovereignty of the islands to Argentina, or other possible legal alternatives, which would only have been formally presented if the vote to remain under British administration had not been the majority option.

${ }_{38}$ In which a new constitution was approved for the territory, endowing it with a greater capacity for selfgovernment and ensuring a more independent judiciary, although the United Kingdom's sovereignty was maintained. 
Other British Overseas Territories have also held referenda. In the referenda held in Anguilla and Bermuda (16 August 1995), the independence option lost. Specifically, in Bermuda, voters were asked to choose between independence and remaining a British overseas territory: $73.6 \%$ voted against independence and $25.7 \%$ for it, with a turnout of $58.8 \%$. The case of the Turks and Caicos Islands was peculiar. Although they were granted independence in 1982, they preferred to retain their status as a British overseas territory.

In general, the British Overseas Territories have chosen to deepen their self-government rather than call for independence. The reason is due to their small size and populations, coupled with their status as tax havens and the importance for them of tourism. These factors are in addition to the weakness, if not outright non-viability, of numerous island and archipelagic countries in their geographic environments.

With regard to the Danish overseas territories, it is worth recalling that on 25 November 2008, a referendum was held in Greenland on greater self-government and a broadening of the territory's statute of autonomy, including the right to self-determination. The "Yes" vote won, with $75.54 \%$ of the inhabitants voting in favour, and the new Act on Greenland SelfGovernment entered into force on 2I June 2009. Thus, Greenland will now decide on strategic areas such the judiciary, as well as on a possible future self-determination, Greenlanders will have control over their resources (such as oil and gas), and Greenlandic will become the sole official language. Meanwhile, Denmark will continue to be responsible for foreign policy.39 Another possible decision could be the total independence of Greenland, giving rise to a new sovereign state. However, there is no specific date for this, as the Greenlandic population and authorities understand that such an option is not viable in the short term. The objective would be to hold an independence referendum by 2020 .

As for the Faroe Islands, as noted, they had called a referendum on a new constitution that would include the right to self-determination for 25 April 20I8. Moreover, another referendum on the territory's independence or integration within Denmark is also planned. The Faroese would also be asked to vote on their accession to supranational organizations, such as the

39 The Statute of Autonomy of Greenland entered into force on 2I June 2009, Greenland's National Day, granting it jurisdiction over the police, the courts and the coast guard and establishing Greenlandic, an Inuit language, as the official language. It also granted it the right to control its own resources. Any bill related to Greenland must be submitted to the Greenlandic Parliament for it to issue an opinion before the vote by the Danish Parliament. Likewise, draft decrees are subject to the prior advisory opinion of the government of Greenland. Foreign policy, defence and monetary policy continue to be the responsibility of the Danish government. A court made up of two representatives of the Danish government, two representatives of the Greenlandic government, and three members of the Danish Supreme Court appointed by the president of the country has jurisdiction over disputes related to the separation of powers. The Greenlandic government may participate in international negotiations on matters that concern it exclusively, except on issues of defence and security. The Greenlandic government may send representatives to Danish diplomatic missions abroad to promote Greenlandic interests. 
European Union, of which the archipelago is not a member. This new constitution would pave the way to independence. It would define the archipelago as a nation and would lay out its rights and obligations as a people, including the right to self-determination. However, the fact of the matter is that, for internal reasons, the referendum has been postponed indefinitely.

In the case of the Danish dependencies, which already have very broad autonomy, the population is divided with regard to proclaiming independence. This is coupled with a clear and highly pragmatic concern not to lose the considerable subsidies that Denmark grants them each year. Indeed, the economy of these territories, like those of most territories with special status, largely depends on the subsidies granted by the government of the parent state.

Finally, unlike the French, British, Danish and Dutch overseas territories, independence has never been foreseen for either the Canary Islands or the Azores Islands or Madeira. Their populations are considered an integral part of the states in which they are included.

\section{FINAL CONSIDERATIONS}

The EU grants some thirty territories scattered around the world a special status for the simple reason that they maintain a particular link with one of its Member States. The moment that link is severed, these territories become third parties with respect to the Union. Whether or not to maintain these constitutional links - which vary depending on the territory and the Member State - is a sovereign power of the Member States. The Union merely takes note in order to adapt the territorial scope of application of European law.

The examination of the internal situations of these territories and the referenda held in them on the future of their relations with the corresponding metropolises shows that, in general, the most popular option is assimilation or greater integration with the parent state. This is followed by movements in favour of greater autonomy, with only a very small minority currently supporting secessionist solutions and total independence.

The reasons for this are manifold: the lack of a truly indigenous population (Falkland Islands or Gibraltar), fear of being absorbed by a problematic third state (Mayotte with regard to the Comoro Islands), the need for economic contributions from the metropolis (virtually all the territories), fear of political instability and/or ethnic clashes (French Polynesia or New Caledonia), concern over the potential secession of parts of their territory (most of the archipelagos have doubts regarding their internal soundness and the islands do not trust each other, e.g. New Caledonia and the Loyalty Islands or the Marquesas Islands and the Society Islands); or fear of becoming an unviable nation (as has occurred in several cases in their respective regions, such as: Vanuatu for various reasons; the micro states in the Pacific that cede their sovereignty to foreign powers; or Haiti, Suriname and Guyana, whose citizens emigrate or seek refuge, precisely in the overseas territories). In short, many of these territories 
with special statuses share the same fear of the "day after" independence, recalling what happened in neighbouring countries that leapt blindly into the void when their respective metropolises withdrew from all administration, virtually overnight.

However, these trends could change, especially with regard to the French overseas territories, which are the largest in terms of both geographical size and population. The recent referendum held in New Caledonia was not clearly favourable to the unionists. Therefore, it could have a domino effect in these territories, which, like Polynesia, are currently seeing a rise in proindependence movements. This trend may be further strengthened by the social and economic crises that many of them are currently undergoing and that, according to local public opinion, are viewed with a growing lack of interest by the states on which they depend. 